UDC 378.21:37.014.24

DOI: 10.15587/2519-4984.2021.248241

\title{
PECULIARITIES OF THE NOSTRIFICATION OF HIGHER EDUCATION DIPLOMAS
}

\section{Serhii Kovalenko}

This article examines the problems of nostrification of foreign diplomas in Ukraine and the recognition of educational programmes, taken by graduates of foreign universities. Ukraine today is a wide market of professions, where our citizens with foreign diplomas and foreigners, who were educated at home, find jobs. The state is also guided by the educational process, which takes place in European countries and has its own characteristics and traditions. Work on universalization of education should have a positive impact on faster and better implementation of programmes of exchange of scientific and pedagogical experience between countries, academic mobility of students, postgraduates, teachers, etc. The article also mentions the traditional exchange of students and professors, the exchange of scientific achievements between universities in different countries, building mutually beneficial partnerships, which is why Ukrainian universities have to focus on the European labour market.

The article also discusses the peculiarities of the document flow for nostrification of diplomas, lists the main documents and reveals the problems, associated with their processing. The research problem has an interdisciplinary status, because it raises problems of documentation work, recognition of diplomas and problems, faced by graduates of foreign universities

Keywords: nostrification of diplomas, higher education, educational programmes, Bologna process, experience, educational process, academic mobility of students, students' exchange programme, labour market, workflow

How to cite:

Kovalenko, S. (2021). Peculiarities of the nostrification of higher education diplomas. ScienceRise: Pedagogical Education, 6 (45), 13-17. doi: http://doi.org/10.15587/2519-4984.2021.248241

(C) The Author(s) 2021

This is an open access article under the Creative Commons CC BY license hydrate

\section{Introduction}

Today Ukraine is actively integrating into the European educational space. Changes are taking place in higher education as a result of new demands of the labour market, in particular, curricula of educational disciplines are being formed closer to the practical institutions of the profession, mastered by the student, and new, more advanced European methods of presenting educational material are being developed. New requirements for teaching staff are being put forward, which should improve the quality of education and its recognition throughout Europe. Traditional student and teacher exchanges, the exchange of scientific advances between universities in different countries and mutually beneficial partnerships are taking place. Therefore, Ukraine should focus on the European labour market. Accordingly, the training of specialists should meet all European standards of education. Considering that Ukraine is a member country of the Bologna Process, we can affirm that the Bologna Process is a means of integrating higher education in the European educational space. This, in turn, has had a positive impact on the faster and better implementation of programmes for the exchange of scientific and pedagogical experience, academic mobility of students, postgraduates, teachers, etc.

\section{Literary review}

Let us note that the outlined scientific problem is within the subject field of such a field of modern pedagogical science as general pedagogy and history of pedagogy, because nostrification of diplomas of higher education in Ukraine has its roots and temporal features.

Y. M. Rashkevych describes the basic principles of the Bologna Process, rights and obligations of students and teachers. The work shows that this educational process should universalize education throughout Europe. Y. M. Rashkevich makes rather positive forecasts, including "intensification of international and interdisciplinary cooperation" [1]. However, the practice, described by the scientist, has a number of obstacles, in particular, on the political and economic level. And here we should talk about the current inconsistency of the educational process in many countries. After all, the process of nostrification is facilitated when the gaps in educational programmes and teaching characteristics are minimal.

A comparison of European and Ukrainian educational systems is made by the authors of the publication [2]. However, their comparisons of the systems come down to perspectives that leave space for us to explore the complex processes of nostrification of higher education diplomas. 
An important breakthrough in the development of knowledge about the features of modern education was a study by V. A. Krechetova [3]. The researcher notes the uniqueness of the student environment and defines its national and civic identity. The study demonstrates that students have time for self-development and transformation of society. However, questions remain unresolved about the adaptation of modern students in a European educational environment, when in the long run education should go in a purely European canons. This leaves us space for analysis of the differences that are bound to appear on the borderline of national and universal.

In the study [4] I. O. Mokhnatyuk considers education as a process of acquiring and transmitting knowledge. The author points out that education serves as a peculiar form of social protection of the population, i.e. there is a direct influence on the economic dominant in the society.

The article by T.V. Drakohrust attracts attention, while analyzing the outlined problem. The scholar devotes attention to the problems of employment in Ukraine of foreigners, educated outside the country, and also their opportunities to obtain diplomas in Ukrainian higher education. And although T. V. Drakohrust pays more attention to the legal aspect, but the problem of harmonization of documentation and educational process remains in the focus of attention [5].

All this points to the interdisciplinary nature of the stated topic and gives grounds to argue that it is advisable to conduct research on nostrification of higher education documents.

\section{Study aims and objectives}

The aim of the study is to examine the problems of recognition of foreign diplomas in Ukraine.

In order to achieve the goal, the following tasks were set:

1. To reveal the concept of nostrification of higher education documents.

2. To analyse the practice of nostrification of higher education diplomas, to find out the peculiarities of its implementation.

\section{Materials and methods}

Employers and university graduates should perceive the diploma as a proof of knowledge and qualification. Therefore, the Ukrainian higher education system should be as close as possible to the European one. Experience shows that a large share of Ukrainians choose education abroad and then return to the realities of their homeland. Questions arise concerning the harmonization of educational curricula, labour market comparisons with European countries, and the recognition in Ukraine of higher education diplomas, acquired abroad by young professionals. Education therefore dictates special conditions for us to develop professional skills and acquire professional knowledge. In this context, the creation of a creative educational environment through the modeling of professional and pedagogical situations - the importance of the influence of the creative educational environment of higher education on the formation of future teachers of humanities subjects to moral and ethical education of high school students is substantiated.
Normative legal documents, regulating the nostrification issues in Europe, include the Lisbon Convention (1997), the Sorbonne Declaration (Paris, Sorbonne, 1998), the Bologna Convention (Bologna, 1999). In Ukraine, the nostrification procedure is carried out in accordance with the Law of Ukraine "On Higher Education" of 01.07.2014, the Law of Ukraine "On Education" of 05.09.2017 and the Order of the Ministry of Education and Science of Ukraine No. 504 of 05.05.2015. (registered with the Ministry of Justice of Ukraine on 27.05.2015, No. 614/27059) "Some Issues of Recognition of Foreign Education Documents in Ukraine".

The following research methods were used to solve the tasks and objectives:

1) theoretical: study, theoretical analysis and synthesis of scientific ideas in pedagogy and jurisprudence;

2) modelling method, used to build a theoretical model of the concept of nostrification in pedagogy;

3) observation method, etc.

Thus, there is a comprehensive scientific approach to the problem of nostrification of foreign diplomas.

\section{Study results and discussion}

The European process, thanks to the significant achievements of the last few years, is becoming an increasingly concrete and relevant reality for the European Union and its citizens. The prospect of enlargement, together with the deepening of relations with other European countries, gives this reality an even greater dimension [6].

Higher education, research and innovation play a crucial role in maintaining social cohesion, economic growth and global competitiveness. Given the desire of European societies to become increasingly knowledgebased, higher education is an essential component of socio-economic and cultural development. At the same time, the increasing demand for skills and competences requires higher education to be able to respond in new ways [7].

It is reasonable to speak about certain contradictions between the need to respond quickly to educational processes in Europe and Ukraine's readiness to respond to them, as well as the need to borrow European experience and the speed of recognition of diplomas of higher education, obtained abroad, in Ukraine, the need to highlight the European experience regarding nostrification and the possibility of its implementation in the Ukrainian educational realities.

In general, the nostrification process is rather complicated and multistage. It will take considerable time to confirm qualifications and recognise the educational document as valid. The procedure involves several successive stages, namely:

1) collecting the documents, stipulated by the legislative acts;

2) payment of the state duty;

3) submission of the application, documents and receipts for the procedure to the Ministry of Education and Science of Ukraine;

4) fulfilment of a number of additional requirements, of which applicants are informed in written form [8]. 
At first glance, it seems easy enough to do all these things. But difficulties arise at the first stage already. Before submitting the educational documents, they must be stamped "Apostille" and/or legalised. At the notary's office the applicant must certify the copies of documents and translation. If a Ukrainian educational institution is involved in the nostrification procedure, a corresponding application from it is required [8].

A successfully completed nostrification procedure will certify that the diploma holder has studied a sufficient number of subjects with a sufficient number of academic hours and has the appropriate qualification. In the process, the educational programme of the foreign country is compared with the educational programme in Ukraine according to the norms of the Ministry of Education and Science of Ukraine.

The term "nostrification" has Latin origin and is translated as "translating into ours" [9]. In the classical sense, nostrification is "recognition of documents on higher education, academic titles and scientific degrees, issued by attestation bodies in other countries" [9]. This procedure is carried out by granting such academic and/or professional rights to the holders of Ukrainian documents on higher education, academic titles and degrees by the relevant public authorities. It is not only the recognition of the equivalence of educational documents in terms of their identity, but also the confirmation of the equivalence of comparative standards of education at the legal international level" [9]. The recognition, the implementation of comparative analysis of foreign documents on education and the issuance of certificates are carried out on the basis of the application of the document holder or the body concerned. Nostrification of certificates, issued to citizens of Ukraine, which certify the fact of awarding academic titles, equivalent to the academic title of professor and associate professor of Ukraine, is carried out by the Ministry of Education and Science of Ukraine on the basis of international agreements and conventions on mutual recognition of academic titles, whose consent to be bound has been given by the Verkhovna Rada of Ukraine. Re-certification of scientific and scientific-pedagogical workers - citizens of Ukraine, who have scientific degrees, awarded to them in other countries, is conducted by the Higher Attestation Commission of Ukraine on petition of the organisation, where the applicant works, with the presentation of doctoral degrees in the list, determined by the Commission. Re-certification of scientific and scientific-pedagogical workers - citizens of Ukraine with academic titles, awarded to them in other countries, is conducted by the Ministry of Education and Science of Ukraine and Higher Attestation Commission of Ukraine on the petition of the organization where the applicant works, with the submission of documents in accordance with the list, determined by the Ministry of Education and Science of Ukraine and Higher Attestation Commission [9].

Issues of re-attestation are considered by Academic Councils on the basis of establishing the equivalence of attestation criteria, applied in another country, to the statutory regulations in Ukraine on the awarding of the academic title of professor or associate professor. A necessary "condition for raising the issue of re-attestation is the replacement of this employee of one of the posi- tions, which will allow applying for the relevant academic title in accordance with the procedure, established in public institutions" of education in Ukraine [10]. If these conditions are met, "at the end of a calendar year of the applicant's work in a given position, the Academic Council has the right to petition for his or her re-attestation. In cases, when it is expedient to determine the level of professional qualification of the employee, who has been awarded earlier academic title of professor or associate professor, due to change of profile or field of its scientific and pedagogical activity or due to changed circumstances and reasons of such requirement, the issue is considered in order of renewed attestation" [10].

Legal regulation of nostrification procedure is carried out on the basis of the Convention on the Recognition of Studies, Diplomas and Degrees in Higher Education in the States of the European Region, 1979, and the Convention on the Recognition of Qualifications concerning Higher Education in the European Region, 1997. In Ukraine, the nostrification procedure is regulated by the Cabinet of Ministers Decree "On Approval of the Procedure for Awarding Academic Degrees and Titles" of 28.VI.1997 and the Order of the Ministry of Education and Science of Ukraine "On the Procedure for Consideration of Certifying Cases on Granting Scientific Degrees and Titles of Higher Education" of 13.XI.1997.

The practice of nostrification has been developed in Ukraine over the years. In particular, there are a number of private firms and state apparatuses, which confirm and nostrify diplomas on higher education.

For a foreign educational document to enter into force on the territory of Ukraine for further employment or to continue studies it may be necessary to undergo the procedure of recognition of documents on education. That is, "to establish the compliance of academic and professional rights, as well as educational and educational qualification levels of foreign documents on education (qualifications) with the state educational standards of Ukraine" [10].

The procedure of recognition in Ukraine of educational documents, issued by educational institutions in other countries, provides for verification of the authenticity of foreign educational documents, submitted for recognition, i.e. verification of the fact of studying and obtaining an educational document.

If legalised documents with an apostille or consular legalisation are provided, this is sufficient to confirm the authenticity of the documents. Consequently, they will not need to verify the fact that they were issued, which will speed up the recognition procedure considerably. However, someone who has submitted documents for nostrification has a choice:

1) one can certify his/her documents according to international law;

2) to have them verified by the State Enterprise "Information and Image Centre" of the Ministry of Education and Science of Ukraine [8].

In order for the documents to be recognised, it is also necessary to verify the official recognition of the educational institution that issued the educational document by the education system of the country, to which it belongs. This stage includes verification of the existence of a certificate of state accreditation of the educational 
institution and a license at the time of the issuance of the educational document.

The next stage in this process is the establishment of equivalence of the qualification, indicated in the foreign document on education, to the requirements to educational or educational qualification levels of the education system of Ukraine, carried out with the involvement of expert commissions on the relevant specialties [8].

Next is a comparative analysis of educational programmes - this is a comparison of educational programmes in content and volume, which is conducted by an educational institution in Ukraine, accredited for the same specialty, which is indicated in the applicant's diploma. If there is no such specialty in Ukraine, the closest one among the existing ones is chosen.

For countries, with which Ukraine has concluded international treaties, establishing the equivalence of documents on education and academic titles to the educational system of Ukraine, i.e. their correspondence to documents on education and academic titles in Ukraine, thus the determination of the educational-qualification level is performed by the Ministry of Education and Science of Ukraine on the basis of relevant international treaties. Such international agreements simplify the recognition procedure but do not abolish its requirements [10].

The nostrification procedure in Ukraine involves the following steps:

1) preparing a set of documents;

2) making an appointment for an interview;

3) submission of documents;

4) examination of the documents by the specialists of the Information and Image Centre of the Ministry of Education of Ukraine;

5) receiving a certificate of nostrification (recognition) of a document [10].

To apply for nostrification the following package of documents is required:

1) original document on education and its supplement (if available);

2) notarized translation into Ukrainian of the educational document and its supplement (if available);

3 ) certificate on the fact of education;

4) other documents necessary for the procedure [10].

The cost and timing of the nostrification procedure depends on the country that issued the educational document.

Before submitting an educational document for nostrification procedure it is necessary to confirm its legality in accordance with the Hague Convention of 1961 . may be:

The result of the recognition procedure in Ukraine

1. Recognition, from which the Certificate of recognition of a foreign educational document is issued. If additional conditions (additional training, competence testing or other actions, non-compliance with which makes it impossible to continue education or professional employment in Ukraine) are determined for the recognition of the holder's qualification', the applicant is notified accordingly [10].
In this case, the holder of education documents must pass examinations in the educational disciplines, specified by the examiners. He/she chooses the institution of higher education on his/her own to take the test, after that the Centre's staff will help to organise the exam in the chosen institution. The deadline for the recognition procedure in such a case lasts until the Centre receives positive test results.

2. Refusal to recognise the submitted education document, of which the applicant is notified, indicating the reasons for such a decision.

As a result of nostrification of diplomas, the holder of foreign educational documents receives a certificate, confirming his/her right to continue their education or obtain employment in Ukraine.

It should be noted, that not all documents, issued by an educational institution of another country, can be recognised in Ukraine. In particular, this applies to:

1) documents, issued by educational institutions, which are not officially recognised (accredited) in the educational system of the country, to which they belong;

2) documents, issued by branches of educational institutions if such branches are not officially recognised (accredited) within the educational system of the country, in the territory of which they perform educational activities;

3) documents that do not contain information on the holder's obtaining a particular educational or professional qualification, professional specialization or professional retraining;

4) documents, issued by an educational institution in another country in violation of the applicable national or international legislation;

5) documents that are not authentic;

6) non-state documents if the country of the applicant's educational institution has adopted an officially approved standard for educational documents;

7) documents, issued as a result of training under the program that cannot be correlated with any educational or educational qualification level and (or) direction of training (specialty, qualification) of the educational system of Ukraine;

8 ) documents that are not recognized in the country, to which the institution belongs;

9) documents that do not contain sufficient information on the content of the educational programme, which makes it impossible to establish the equivalence of the qualifications, assigned by these documents to the educational or educational qualification level of the educational system of Ukraine [10].

Documents on education of citizens of the former USSR, issued before 15 May 1992, do not require recognition in Ukraine since, in accordance with Article 5 of the Agreement on cooperation in the field of education, signed in Tashkent in 1992, the participating states guaranteed indefinite recognition in their territories of the documents on education, issued in the participating states by the time of signing of the above-mentioned Agreement. Member states are: the Republic of Azerbaijan, the Republic of Belarus, the Republic of Armenia, the Republic of Kazakhstan, the Kyrgyz Republic, the Republic 
of Moldova, the Russian Federation, the Republic of Tajikistan, Turkmenistan, the Republic of Uzbekistan.

The procedure of recognition of foreign education documents implies the following:

1. Verification of the authenticity of foreign educational documents, submitted for recognition (verification of the fact of training and issuance of documents).

2. Verification of state accreditation certificate and license of the educational institution, which issued the document.

3. Establishing the equivalence of qualifications, indicated in foreign documents on education, educational qualification level, which corresponds to the norms of the educational system of Ukraine (carried out with the involvement of expert commissions on specialities) [10].

The following documents are not subject to the recognition procedure:

- documents, issued by educational institutions, which do not have official registration (accreditation) as an entity, providing educational services in the country where they belong

- documents, issued by the branches of educational institutions, if such branches are not officially registered (accredited) as an entity, providing educational services in the country they belong to

- documents, which do not contain information on obtaining a specific educational or educational qualification level, for which the holder has academic or professional rights (continuing education or employment in the specialty)

- non-state documents of the countries, international agreements with which provide recognition only of documents, corresponding to the state sample [10].
The study of nostrification of documents is quite a broad problem, which cannot be exhausted only from one perspective and requires further solution. This study will contribute to further improvement and optimisation of the system of nostrification of higher education documents and the maximum harmonisation of educational programmes.

\section{Conclusions}

1. Nostrification, a documented process, has its own stages of progression. It is related to the peculiarities of educational programmes in different countries. The recognition of diplomas has a clear algorithm, set out in legislation. A successfully completed nostrification procedure will attest that the diploma holder has studied a sufficient number of subjects with a corresponding number of academic hours and has a corresponding qualification.

2. Having analysed the practice of nostrification of higher education diplomas and having clarified its peculiarities, we can see that the indicated problem unfolds according to a strict scenario. In the process of confirming a foreign diploma the educational program of another country is compared to the educational program in Ukraine in accordance with the standards of the Ministry of Education and Science of Ukraine. Nostrification of higher education documents allows the applicant to realize his/her potential in Ukraine, to demonstrate the skills and abilities, acquired in another country, to apply the technologies, tested in European countries. Our research problem is important to compare and analyse the educational process and monitor the quality of educational services in Ukraine and EU countries. In the future, the experience gained should influence the universalisation of higher education.

\section{References}

1. Rashkevych, Y. (2018). The Bologna process: history, current state and perspectives. Educational Analytics of Ukraine, 3 , 5-16. doi: https://doi.org/10.32987/2617-8532-2018-3-5-16

2. Artomov, I. V., Studeniak, I. P., Holovach, Y. Y., Hus, A. V. (2015). Innovatsii u vyshchii osviti: vitchyznianyi i zarubizhnyi dosvid. Uzhhorod: PP «AUTDOR-ShARK», 360.

3. Krechetova, V. A. (2018). Vyshcha shkola yak chynnyk formuvannia hromadianskoi identychnosti studentiv u suchasnii Ukraini. Zaporizhzhia, 21.

4. Mokhnatiuk, I. O. (2010). Osoblyvosti suchasnoi osvity: sotsiokulturno-tsinnisnyi vymir. Filosofski problemy humanitarnykh nauk, 19, 165-170.

5. Drakokhrust, T. V. (2017). Features of legal regulation of legislation of Ukraine to protect the rights of foreigners and stateless person. Yurydychnyi naukovyi elektronnyi zhurnal, 1, 190-193.

6. The European Higher Education (1999). Joint Declaration of the European Ministers of Education. Bologna. Available at: https://www.eurashe.eu/library/bologna_1999_bologna-declaration-pdf/

7. Standards and Guidelines for Quality Assurance in the European Higher Education Area (ESG) (2015). Available at: https://www.enqa.eu/wp-content/uploads/2015/11/ESG_2015.pdf

8. Apostyl na dokumenty pro osvitu. Informatsiino-imidzhevyi tsentr, Derzhavne pidpryiemstvo Ministerstva osvity i nauky Ukrainy. Available at: https://apostille.in.ua/ua/

9. Berezovska, S. V. Nostryfikatsiia. Yurydychna entsyklopediia. Available at: https://leksika.com.ua/19740122/legal/nostrifikatsiya

10. Vyznannia inozemnykh dokumentiv. Ministerstvo osvity i nauky Ukrainy. Available at: https://mon.gov.ua/ua/ministerstvo/ poslugi/viznannya-inozemnih-dokumentiv

Received date 05.10.2021

Accepted date 09.11.2021

Published date 30.11.2021

Serhii Kovalenko, Vice-Rector Assistant for Foreign Students, Postgraduate Student, Department of Theory and History of Pedagogy, Borys Grinchenko Kyiv University, Bulvarno-Kudryavska str. 18/2, Kyiv, Ukraine, 04053 E-mail: s.kovalenko.asp@kubg.edu.ua 